\title{
5 RELIGION, CITIZENSHIP AND THE STATE OF ZIMBABWE: THE POLITICS OF ZIMBABWE'S FIRST LADY GRACE MUGABE
}

\section{Prosper Muzambi ${ }^{1}$}

\section{INTRODUCTION}

The Constitution of Zimbabwe Act, 2013 has, as one of its fundamental human rights and freedoms, the freedom of conscience, which includes freedom of thought, opinion, religion or belief. ${ }^{2}$ Despite having this constitutional element of citizenship in Zimbabwe, I argue that the various theories of a theologically informed citizenship that offer what an ideal society ought to be are largely unrealised in the Zimbabwean context. ${ }^{3}$ This is particularly the case because those in authority manipulate religion to give legitimacy to their rule. In addition, they make use of scriptural texts that advocate subjection of citizens to those in power and a perpetual maintenance of the status quo. In this connection, the political enunciations of First Lady Grace Mugabe, despite her lack of expertise in the area of biblical hermeneutics, are the focus of this study.

\section{THEORIES OF CITIZENSHIP}

Towards the end of the 1970s, it was argued that "the concept of citizenship has gone out of fashion among political thinkers". ${ }^{4}$ However, political theorists Will Kymlicka and Wayne Norman assert that there has been an explosion of interest in the concepts of citizenship among political theorists. ${ }^{5}$ Historian of civic engagement David Scobey has referred to this revival as the "return of the citizen' in public and policy discourse." ${ }^{\prime 6}$ Moreover, this efflorescence is a reflection of a growing belief in many quarters that we are living in what sociologist and former President of Brazil Fernando Henrique Cardoso has

1 Prosper Muzambi is a lecturer of Theology at Great Zimbabwe University, Masvingo, Zimbabwe, and also a PhD student in Theology and Development at the University of KwaZulu-Natal, South Africa.

2 Constitution of Zimbabwe Amendment (No. 20) Act, 2013, Chapter 4, Part 2, Section 60.

3 The research in this chapter is guided by the conceptualisation of this term by Kymlicka W and Norman W. 1994. "Return of the Citizen: A Survey of Recent Work on Citizenship Theory", Ethics 104(2):352-381. These two contend that a citizen is "someone who has democratic rights and claims of justice". The researcher argues that such ingredients constitute a "healthy state of belonging by inhabitants of any community".

4 Van Gunsteren H. 1978. "Notes towards a Theory of Citizenship", in Dallmayr F (ed). From Contract to Community. New York: Marcel Decker, 9.

5 Kymlicka and Norman, "Return of the Citizen", 352.

6 Scobey D. 2001. “The Specter of Citizenship”, Citizenship Studies 5(1):11-26, 20. 
referred to as "an age of citizenship". 7 This change came about in the mid1990s when the concept of citizenship became a "buzzword" in the realm of political thought. ${ }^{8}$ Political historian Richard Bellamy expressed it succinctly when he asserted that "interest in citizenship has never been higher. Politicians of all stripes stress its importance, as do church leaders, captains of industry, and every kind of campaigning group - from those supporting global causes, such as tackling world poverty, to others with a largely local focus, such as combating neighbourhood crime." ${ }^{9}$ Governments across the world have promoted the teaching of citizenship in schools and universities and introduced citizenship tests for immigrants seeking to become naturalised citizens. " ${ }^{10}$ Types of citizenship proliferate continuously, from dual and transnational citizenship, to corporate citizenship and global citizenship." A list of types of citizenship is provided by Peter Kivisto and Thomas Faist. ${ }^{11}$ Whatever the problem, be it the decline in voting, increasing numbers of teenage pregnancies, political polarisation, intolerance of others' conceptualisations of the world values, gripping onto power for too long, or climate change, someone has canvassed the revitalisation of citizenship as part of the solution.

Articles in a book edited by theologian David Kaulemu offers some insights on how citizenship is conceptualised in the Zimbabwean context. ${ }^{12}$ In his editorial note, Kaulemu notes that those who responded to his call for contributions to a book on citizenship in Zimbabwe were quite telling. His reading of the responses revealed that there was a general reluctance to talk explicitly about the ontological and spiritual identity of Zimbabwe and how that identity informs the way in which citizenship is imagined. There are many questions that Zimbabweans still hesitate to talk about in public, even though we will sometimes admit to our prejudices in private. As Zimbabweans, we shy away from public discourse unless we are assured of acceptance and victory. The universal common good is alien to our psyche. Since colonisation in 1890, the culture of fear can be found in the majority of Zimbabwean citizens. ${ }^{13}$ This fear has helped some politicians' hold to power by appealing to a fallacy that their being in power is God-ordained. To this regard, I focus on the constitutional community of Zimbabwe, rights of freedom of conscience, and social and

7 Cardoso FH. 2000. "An Age of Citizenship", Foreign Policy 119:40-42.

8 Heater D. 1990. Citizenship: The Civic Ideal in World History, Politics, and Education. London: Longman, 293; Vogel U and Moran M. 1991. The Frontiers of Citizenship. New York: St. Martin's, x.

9 Bellamy R. 2008. Citizenship: A Very Short Introduction. Oxford: Oxford University Press, 1.

10 Mavhunga PJ, Moyo N and Chinyani H. 2012. “Towards a Citizenship Education for Zimbabwe", Zimbabwe Journal of Educational Research 24(1):47.

11 The summary of various treatments of citizenship is found in Kivisto P and Faist Thomas. 2007. Citizenship: Discourse, Theory, and Transnational Prospects. Malden, MA: Blackwell, 2.

12 David K. 2013. Imagining Citizenship in Zimbabwe. Harare: The Konrad-AdenauerStiftung (KAS).

13 David, Imagining Citizenship in Zimbabwe, vi. 
political development. These three components are important in pointing out the need for social and political flexibility and the need to bring out opportunities for change, evolution, and an advancement of a citizenship that is not enslaved by the culture of fear which is part of the Zimbabwean inheritance from the colonial past.

\section{THE CONSTITUTIONAL COMMUNITY OF ZIMBABWE}

The background of the Constitution of Zimbabwe, 2013 stretches to the colonial period. Though Zimbabwe was colonised in 1890, it operated as a British Protectorate until 11 November 1965, when the Rhodesian Front (RF) led by Ian Smith made a Unilateral Declaration of Independence (UDI). ${ }^{14}$ This was a political declaration made by the RF to cut legal ties with the British Crown. The British government and the majority of black nationalists wanted to have a constitution guaranteeing recognition of the rights of the majority, who were the blacks of Zimbabwe before the declaration of independence. Despite its being designated "a blow for the preservation of justice, civilisation and Christianity"15 by Ian Smith, the UDI was a legal instrument only representing the interests of the colonials. There was no referendum to come up with this political stance. Instead of establishing peace, it created a rise of nationalistic politics of resistance by blacks and a few white people who were against the injustices of a minority white regime. After a protracted struggle for independence, a new Constitution was crafted through negotiations of political parties of Zimbabwe under the guidance of the British government in 1979 at Lancaster House, and it came to be known as the Lancaster Constitution (LC). ${ }^{16}$

The current Constitution was ushered in as a result of the need to replace the LC, which came into operation on 18 April 1980. The LC was subsequently amended, mainly due to its being archaic and thus irrelevant and inapplicable to the contemporary trends challenging the Zimbabwean community. Though Zimbabwe declared itself independent in 1965, its independence was not recognised until 1980. Thus, the LC became the first constitution of independent nation, but it still reflected colonial terms, since it was a negotiation and compromise between representatives of warring factions namely the whites of the Rhodesian Front led by Ian Smith, on one hand, and by black nationalistic movements, including Zimbabwe African People's Union-ZAPU, the Zimbabwe African National Union-ZANU of Robert Mugabe and Abel Muzorewa's United African National Council - UANC. ${ }^{17}$ The drafting of the Constitution

14 Lapsley M. 1986. Neutrality or Co-option? Anglican Church and State from 1964 until the Independence of Zimbabwe. Gweru: Mambo, 15.

15 Lapsley, Neutrality or Co-option?, 15.

16 This Constitution of Zimbabwe was published as a Schedule to the Zimbabwe Constitution Order 1979 (S.I. 1979/1600 of the United Kingdom).

17 ZAPU and ZANU are revolutionary parties that were particularly instrumental in the liberation struggle from colonial rule. These two parties entered into an agreement to have a common cause in the fight against colonialism. However, 
mainly involved three political parties that were then part of the Government of National Unity (GNU), namely, the Zimbabwe African National Union Patriotic Front (ZANU-PF), the Movement for Democratic Change-Tsvangirai (MDC-T), the Movement for Democratic Change-Mutambara (MDC-M). ${ }^{18}$ After the violence, and political struggle of the last decade (2000-2010), and thirty years of one-party rule, Zimbabwe embraced coalition government and the multi-party sharing of power. ${ }^{19}$ In 2008, the power-sharing deal provided the structure for much of the government. Establishing the conditions for the sharing of that power, the Global Political Agreement (GPA) was fostered by the "quiet diplomacy" of former South African President Thabo Mbeki and the Southern African Development Community (SADC). Since the adoption of the GPA, and as it dictated, Zimbabwe underwent a participatory constitutionmaking process, the culmination of which was a new draft constitution for its people to adopt or reject by referendum, led by the Constitutional Parliamentary Select Committee (COPAC). This is the background of the constitutional inheritance, whose various successes and failures are not part of the scope of this research. However, the fact that the exercise of coming up with the draft constitution involved the consultation of citizens shows an embrace of participatory democracy during the constitution-making process in Zimbabwe. It was thus a people-driven constitution, which was a positive response to the call of Lovemore Madhuku, who is one of the leading constitutional lawyers in Zimbabwe.

Consultations at grassroots level were made and a number of civic groups that also included religious organisations. Examples of these civic groups include the National Constitution Assembly (NCA) led by Lovemore Madhuku, the Catholic Commission for Justice and Peace (CCJP), Coalition Zimbabwe (CZ), the Zimbabwe Council of Churches (ZCC) helped in educating the Zimbabwe populace on key constitutional issues. A referendum that ushered in the new Constitution was held on 16 March 2013. The parliament approved it

in 1980, they contested the elections separately. Joshua Nkomo's ZAPU was defeated by Robert Mugabe's ZANU. A struggle for political space between these two political parties claimed several lives. A truce was reached and sealed by the signing of what is now celebrated as the Unity Accord on 22 December 1987. The unity of these two culminated in the formation of Zimbabwe African National Union Patriotic Front (ZANU-PF).

18 Various splinter parties from the original Movement for Democratic Change (MDC) of 1999 came about as a result of internal disagreements among the leadership. Welshman Ncube, the Secretary General of the Movement, and Gibson Sibanda, who deputised Morgan Tsvangirai and others, formed a splinter group of this movement. Besides the power sharing matrics issues, some analysts saw a regional card at hand to this breakaway due to the fact that the top brass of the splinter group were from the southern part of Zimbabwe, a region that mainly consists of Ndebele-speaking people.

19 Sokwanele. 2012. "Reflecting on Zimbabwe's constitution-making process", August. Online at: http://archive.kubatana.net/docs/demgg/sokw_reflect_constitution_ making_120808.pdf 
on 9 May $2013 .^{20}$ It is this 2013 Constitution that I make use of to inform the findings of this study on the place of citizens in light of the right to religion from a Zimbabwean perspective.

\section{RIGHTS OF FREEDOM OF CONSCIENCE AND POLITICAL DEVELOPMENT}

From a global perspective, the right to religion is traced from the 1948 Universal Declaration of Human Rights (UDHR), which asserts that "everyone has the right to freedom of thought, conscience and religion; this right includes freedom to change his or her religion or belief, and freedom either alone or in community with others and in public or private, to manifest his or religion or belief in teaching, practice, worship and observance." ${ }^{21}$ Many states around the globe have similar sections on freedom of thought, conscience, opinion, religion or belief for various reasons. ${ }^{22}$ First, many states are members of the United Nations and signatories to the Universal Declaration of Human Rights (UDHR). The UDHR is also the most immediate progenitor of Article 18 of the International Covenant on Civil and Political Rights (ICCPR), which guarantees religious freedom. ${ }^{23}$ As of 7 July 2003, 149 states, representing approximately three-quarters of the world's states, had signed and ratified the ICCPR. ${ }^{24}$

20 Wikipedia, "Constitution of Zimbabwe".

21 Universal Declaration of Human Rights, G.A. res 217A (III), UN. Doc A/810 at 71 (1948), art 18. See also Vinod S (ed). 2002. Human Rights Violations A Global Phenomenon. New Dehli: A.P.H. Publishing Corporation, 36; Roth Hans-Ingvar. 2016. "Freedom of Religion as a distinct human right", in Coertzen P, Green MC and Hansen L (eds). Religious Freedom and Religious Pluralism in Africa - Prospects and Limitations. Stellenbosch: African Sun Media, 15.

22 An elaborate coverage of issues on legal instruments focusing on religion and secular beliefs is found in Lerner N. 2006. Religion, Secular Beliefs and Human Rights - 25 Years After the 1981 Declaration. Boston: Martinus Nijhoff. As a way of concretising the issue of similarity, I have singled out the South African context because of its close proximity and ties with Zimbabwe. For this, the book chapter by Denise Meyerson is helpful. See Meyerson D. 2005. "Religion and the South African Constitution", in Radan P, Meyerson D and Coucher RF (eds). Law and Religion: God, the State and the Common Law. London \& New York: Routledge, 107.

23 The principal international law provision for the protection of an individual's right to freedom of religion is found in Article 18 of the International Covenant on Civil and Political Rights, G.A. res. 2200A (XXI), 21 U.N. GAOR Supp. (No. 16) at 52, U.N. Doc. A/6316 (1966), 999 U.N.T.S. 171, entered into force Mar. 23, 1976. A further in-depth discussion can be found in Radan et al. (eds), Law and Religion: God, the State and the Common Law, 12-15.

24 Radan et al. (eds), Law and Religion: God, the State and the Common Law, 8. Ratification of a treaty binds a State Party to its terms, subject only to reservations made by the ratifying State Party. A reservation has the effect of rendering as non-binding that part of the treaty that is the subject of the reservation. Zimbabwe signs some international, continental or regional treaties, but it requires further legislative ratification. 
Populous states that have not signed and ratified this treaty include China, Indonesia, Pakistan, Saudi Arabia and Turkey. ${ }^{25}$

Second, states may belong to continental and regional blocks with treaties that require them to respect peoples' freedom of conscience, belief, thought or opinion. For instance, Zimbabwe is a member of the African Union (AU), formerly known as the Organisation of the African Unity (OAU) ${ }^{26}$ On the African region, the guidance is drawn from the African Charter on Human and People's Rights (ACHPR). ${ }^{27}$ Part of the ACHPR addresses on rights and duties of both the States and citizens. Human rights law scholar Bronwen Manby considers obligations of Member States to recognise and give effect to the rights in the ACHPR, to non-discrimination and equal protection of the law, to life, to dignity, to liberty and to fair trial. ${ }^{28}$ This is enshrined in Articles 1 to 7 of the Charter. Member States are obliged to recognise the rights, duties and freedoms enshrined in the ACHPR and are also obliged to undertake to adopt legislative or other measures to give effect to them. ${ }^{29}$ Citizens are protected by Article 2 of ACHPR, which states that "Every individual shall be entitled to enjoyment of the rights and freedoms recognised and guaranteed in the present Charter"

On the social and religious fronts, citizens are protected by Article 8 of the ACHPR, which specifically spells out that there is "freedom of conscience, the profession and practice of religion shall be guaranteed. No one may, subject to law and order, be submitted to measures restricting the exercise of these freedoms" and Article 27.2 of the Charter which spells out that "the rights and freedoms of each individual shall be exercised with due regard to the rights of others, collective security, morality and common interest." In a discourse on citizenship in Zimbabwe, freedom of conscience and religion is of paramount importance, not least because its enjoyment adds value to the dignity and selfrespect of the individual. It is also an essential complement to the guarantee of

25 Radan et al. (eds), Law and Religion: God, the State and the Common Law, 8.

26 The African Union (AU) is a continental union consisting of all 55 countries on the African continent. It was established on 26 May 2001 in Addis Ababa, Ethiopia, and launched on 9 July 2002 in South Africa with the aim of replacing the Organisation of African Unity (OAU). The most important decisions are made by the heads of state and government of its member states. The AU's secretariat, the African Union Commission, is based in Addis Ababa. See Wikipedia, "African Union".

27 African [Banjul] Charter on Human and Peoples' Rights, adopted 27 June 1981, OAU Doc. CAB/LEG/67/3 rev. 5, 21 I.L.M. 58 (1982), entered into force Oct. 21, 1986.

28 Manby B. 2008. "Civil and Political Rights in the African Charter on Human and People's Rights: Articles 1-7", in Evans M and Murray R (eds). The African Charter on Human and People's Rights - The System in Practice. Second Edition. New York: Cambridge University Press, 171. See also Kolawole O. 2008. "Civil and Political Rights in the African Charter 8-14", in Evans and Murray (eds), The African Charter on Human and People's Rights, 215.

29 Taken from Article 1 of the ACHPR. This should be read in conjunction with Article 25 of the same Charter, which spells out the duty of States to promote these rights and obligations through education. 
the right to freedom of expression and opinion guaranteed by Articles 60 and 61 of the Constitution of Zimbabwe.

Malcolm Evans and Rachel Murray assert that the ACHPR is unique in that it lacks a precedent in Africa. ${ }^{30}$ In an earlier publication, Murray contends that the provisions of the earlier OAU Charter make little express mention of human rights. ${ }^{31}$ Instead they reflect the dominating concerns of Africa at that time, namely to ensure the independence of those African peoples who were still colonised, condemnation of apartheid regimes in southern Africa, and protecting the newly acquired statehood. ${ }^{32}$ Baricako asserts that more than thirty years passed after the adoption by the General Assembly of the United Nations of the UDHR before the African continent equipped itself with a regional mechanism for the promotion and protection of human and peoples' rights. ${ }^{33}$ However, the idea of drafting a human rights convention, with an organ charged with its implementation, began to take root in the 1960s. Nothing immediately followed this initiative. Instead, it took three decades since the establishment of OAU before the ACHPR became a reality. This shows that the OAU Charter was more focused on states rather than the citizens, hence the need for an ACHPR. This was an incomplete conceptualisation of the ideals of citizenship by African nationalists and a pointer to the challenges of human rights abuse in many parts of Africa including Zimbabwe today.

Third, the influence of the United States in its quest to protect fundamental human rights cannot be ignored and has been influential in the African context. This has been one of its founding principles dating back over 200 years. A central goal of U.S. foreign policy is the promotion of respect for human rights as enshrined in the 1948 UDHR. Vinod Sharma avers that "the United States understands that the existence of human rights helps secure the peace, deter aggression, promote the rule of law, combat crime and corruption, strengthen democracies, and prevent humanitarian crises." ${ }^{\prime 34}$ The U.S. Embassy in Harare, Zimbabwe plays a human rights monitoring role, despite being accused by

30 Evans and Murray (eds), The African Charter on Human and People's Rights, unpaginated note to the second edition of the book done by the editors of the book.

31 See OAU Charter, Addis Ababa, 25 May 1963.

32 Murray R. 2004. Human Rights in Africa - From the OAU to the African Union. Cambridge: Cambridge University Press, 7. The same view is also in an introductory preface by Germain Baricako, former Secretary of the African Commission in the same volume. See Baricako G. 2008. "The African Charter and African Commission on Human and Peoples' Rights", in Evans and Murray (eds), The African Charter on Human and People's Rights, 1. Furthermore, it has been suggested that the OAU was not initially willing to consider human rights, labelling them "one of the main elements in the ideological armoury of imperialism". Shivji IG. 1989. The Concept of Human Rights in Africa. London: CODESRIA Book Series.

33 Baricako, "The African Charter and African Commission on Human and Peoples' Rights", 1.

34 Sharma V (ed). 2002. Human Rights Violation, A Global Phenomenon. New Delhi: A.P.H., 209. 
the Zimbabwean authorities of interfering in internal affairs of a sovereign state. A recent statement by the U.S. Embassy maintained, "The United States notes with concern reports of the abduction, assault, and harassment of civil society leaders". ${ }^{35}$ Within Zimbabwean civil society, Pastor Evan Mawarire is an example of a religious figure whose Christian principles made him become a conscientious objector. His call for the government to be accountable to its citizens earned him an arrest. The U.S. Embassy in Harare called for his immediate release. ${ }^{36}$

The Constitution of Zimbabwe quoted verbatim categorically states:

60 Freedom of conscience

(1) Every person has the right to freedom of conscience

(a) Freedom of thought, opinion, religion or belief,; ${ }^{37}$

(b) Freedom to practice and propagate and give expression to their thought, opinion, religion or belief, whether in public or in private and whether alone or together with others.

Freedom of religion is thus enshrined in the supreme law of the land. There is no prescribed religion for Zimbabwean citizens. Zimbabwe is a multi-religious state ${ }^{38}$ though Christianity is the dominant religion. The religious demographic breakdown in 2012 estimates of religious affiliation in Zimbabwe is as follows: Christianity (including syncretic forms): $85 \%$; African traditional religions: 3\%; Islam and other religions: less than 1\%; and non-religious: $12 \%$. Percentages are based mainly on the 2010-11 demographic survey. The government does not require registration of religious groups. These affiliations assume a population of 12 million. Due to emigration during the recent years of crisis, estimates of the nation's current population varies between 11 and 13 million. ${ }^{39}$

In light of this, chances are that political gatherings in Zimbabwe are likely to be constituted by adherents of religion - with Christians occupying a staggering figure of around $85 \%$. With this background in mind, it is easy for politicians to deliver speeches coloured with religious undertones to an already religion-gullible

35 United States Embassy in Zimbabwe. 2017. “US Statement on deteriorating Human Rights Situation in Zimbabwe", 6 February. Online at: https://zw.usembassy.gov/ statement-deteriorating-human-rights-situation-zimbabwe/?_ga=1.46040100.162 4371614.1491931553

36 2017. "US Embassy Harare calls for immediate release of Pastor Evan Mawarire", Pindula News, 4 February.

37 This is similar to the Constitution of the Republic of South Africa, 1996, s 15. See Meyerson, "Religion and the South African Constitution", 107.

38 Chitando E. 2011. "Prayers, politics and peace: The church's role in Zimbabwe's crisis". Online at: http://www.osisa.org/sites/default/files/sup_files/Prayers $\% 2$ C $\% 20$ politics\%20and\%20peace.pdf. In this presentation, Chitando asserts that although Zimbabwe is a multi-religious country, Christianity controls a major share of the spiritual market. As a result, the institution of the church will always play a role in social, political and economic issues - whether it actively seeks to or not.

39 See "Religions in Zimbabwe: Major Religions". Online at: https://relzim.org/ major-religions-zimbabwe 
audience. Indeed, biblical scholar Masiiwa Ragies Gunda maintains that "the Christian Bible has been extensively used in the public sphere by politicians, judges, industrialists and religious functionaries in such ways as to raise critical questions about the nature of development we aspire for as Zimbabweans." 40 In this context, the use of the Christian Bible by First Lady Grace Mugabe in the public sphere raises particular questions: Is her resort to religion for the promotion of tolerance and respect of voices that challenge the status quo? Or is it for the perpetuation of the status quo and a blind following of a leadership that some see as incompetent, retrogressive, corrupt and oppressive? At the very centre of these questions is a suspicion of the utilisation of religious and theological positions by politicians as they try to legitimise their authority to remain in power.

From their socio-political reading of the Old Testament, biblical scholars Robert B Coote and Mary P Coote have argued that David used religion to legitimise his authority. ${ }^{41}$ Respect for the king was conversely related to respect for Yahweh. The few literate people in David's court marketed this ideology to the general public. I argue that today we can re-read the story of David and his successors and assert that these leaders imposed on their subjects the equation that good citizenship was equal to loyalty to the rulers and consequently to Yahweh. Transposing this to the Zimbabwean context, does this re-reading of the Bible promote the protection of freedoms by advancing both civil and political rights and also economic, social, and cultural rights in the sense of the two key U.N. covenants on these rights categories? Are there any tensions around these that cause people to think that their rights as citizens are not being respected and advanced?

Political scientist Frans J Vestraelen has written on religion-state relations in Zimbabwe. Vestraelen's studies focus on the condition of the state in Africa, investigating particularly why and how Christianity relates to politics. Verstraelen describes religion-state relations during the various eras of Zimbabwe's history from a historical and missio-theological perspective. On the precarious state of the state in Africa, Verstraelen writes, "Unfortunately, in the process of nation-building, the State became more or less coterminous

40 Gunda RM. 2012. "Rewriting" the Bible or De-biblifying the Public Sphere? Proposals and propositions on the usage of the Bible by public figures in Zimbabwe", in Gunda RM and Kugler J (eds). The Bible and Politics in Africa. Bamberg: University of Bamberg Press, 22. Masiiwa Ragies Gunda holds a PhD from Bayreuth University in Germany. He taught Old Testament Studies at the University of Zimbabwe and is one of the founding editors of the Bible in Africa Studies (BiAS) series. His main research interests are on the Bible as an ancient living text.

41 Coote RB and Coote MP. 1993. "Power, Politics, and the Making of the Bible: The Torah", in Gottwald NK and Horsely RA (eds). The Bible and Liberation: Political and Social Hermeneutics. Maryknoll, NY: Orbis, 347, 348. 
with its leaders, who considered the State as their political earning" 42 - and a heritage which cannot be passed on to the next generation during their lifetime.

Today, almost twenty years after Verstraelen's findings, the situation has not changed for the Zimbabwean context. If anything, the credentials of being war veterans of the liberation struggle in Zimbabwe are an indispensable prerequisite for those who harbour ambitions to occupy leadership positions - a passport to have the "right" to walk in the corridors of power. Being a war veteran gives one the aura of being a privileged citizen. Such voices have become louder within the ranks and files of ZANU-PF. If one does not have this in one's curriculum vitae, at least a close relationship with those who have it can work in one's favour. As far as ZANU-PF is concerned, election campaigns are "incomplete" if the liberation struggle is precluded. ${ }^{43}$ The liberation struggle, popularly known as Chimurenga, came in two phases. The first was the 1896/7 Shona/Ndebele Uprisings against colonial rule. The second started in the 1960s and ended in 1979 after the Lancaster-negotiated talks that brought in the first constitution of independent Zimbabwe. Even so, not all members of ZANU-PF leadership are veterans of the struggle for liberation, hence the call to revisit and redefine citizenship in Zimbabwe. This is needed if the state is to forge ahead with an all-inclusive citizenship. Inasmuch as the heritage of the liberation struggle is not to be discarded, the contributions of a generation that did not participate in the struggle can also help in shaping a citizenship that respects the freedoms referred to in this paper.

A further interrogation of generational clashes can also be transferred to other sectors of the Zimbabwean populace. This means that present day Zimbabwe is made up of the liberation generation and the post-liberation generation. ZANU-PF is now made up of those who were born in the 1970s and could not have participated in the struggle for liberation. Some of these are now in their forties in terms of age and they see themselves as inheritors of the political heritage that brought independence. As they keep close relations with the old guard of the liberation, they are very much conscious of the need to take the reins of power from the aging participants of the liberation struggle. Grace Mugabe, who is now in her early fifties, fits within the post-liberation generation. Alex Magaisa, a U.K.-based lecturer in law who was one of the authors of the current Constitution of Zimbabwe, argues that ZANU-PF is now faced with a generational conflict and that the military has not been spared. He says that the "generals are involved in a war of generations. The liberation

42 Verstraelen FJ. 1998. Zimbabwean Realities and Christian Responses: Contemporary Aspects of Christianity. Gweru: Mambo, 45.

43 The liberation struggle (also known as Chimurenga/Umvukela) to which I am referring is the protracted fight against white colonial rule which began in the early 1960s and ended in 1979 after the 1979 Lancaster Talks. This noble war to restore justice is acknowledged in the preamble of the Constitution of Zimbabwe 2013 in the commendation: "Exalting and extolling the brave men and women who sacrificed their lives during the Chimurenga/Umvukela and national liberation struggles". See also Wikipedia, "Chimurenga". 
generation wants to hold on to power against the post-liberation generation, which wants to wrest control of the party leadership." 44 I argue that this has been exacerbated by the rise to power of Grace Mugabe, who belongs the postliberation generation, but is closely associated with one of the icons of the liberation generation by virtue of marriage.

In religious circles, marriage is held in high esteem. The Bible tells stories of people who strategically married to advance political interests. Solomon is an example. He married many foreign women. He thus formed political alliances to foreign nations by marriage (1 Kings 3:1-2). ${ }^{45}$ Religiously, the women brought along with them to the king's palace their religious heritage from foreign lands (1 Kings 11:1-3). In a similar way, but across generations instead of nations, Grace Mugabe married Robert Mugabe, the President of the Republic of Zimbabwe, in 1996. ${ }^{46}$ The marriage was done in accordance with both the traditional customary law and the canons of the Catholic Church in a Christian ceremony which emphasises the importance of the sacrament of matrimony. ${ }^{47}$ Grace brought along with her the post-liberation generation ideology. The moral implication of the marriage of Grace to Robert Gabriel Mugabe is not the issue of this chapter. However, it suffices to say that the importance of religion in the union cannot be overlooked. It was a precursor of how the biblical text would be used by the First Lady as she launched her political career.

\section{THE POLITICS OF CITIZENSHIP IN ZIMBABWE: A HERITAGE OF THE (AB)USE OF RELIGION}

Reflecting on the politics of citizenship in Zimbabwe, one is faced with a number of issues. For this study, I note that it is important to ask if the Bible is not being used to abuse the public in attendance at political rallies or those who sit at home and watch the national television channel which beams live coverage of these rallies. Closely related to this is the need to probe whether this is a heritage of the (ab)use of religion by wielders of political power. Recent scholarship on religion and politics indicates an intermingling between religion and politics around the globe, in general, and Zimbabwe, in particular. Catholic theologian Joachim Kugler argues that "in antiquity ... there is no kind of religion without political dimension and I even dare to doubt that a non-political religion exists

44 2016. "Military fracturing as ZANU-PF wars intensify' in Newsdzezimbabwe", News Journal Search South Africa Edition 12 September.

45 Hill AE and Walton JH. 2009. A Survey of the Old Testament 3rd Edition. Grand Rapids, MI: Zondervan, 295.

46 Though some sections of society have reservations about this union, which started off as adulterous due to the fact that these two had a child, whilst Sally (Robert Gabriel Mugabe's first wife) was still battling with kidney problems, I have no intention to deal with the moral implications of this marriage.

47 1994. Catechism of the Catholic Church. London: Geoffrey Chapman, 358-372; 1983. The Code of Canon Law. London: Collins Liturgical, Canon 1055-1165. 
today". ${ }^{48}$ It therefore comes as no surprise that politicians in Zimbabwe, despite their lack of authority in biblical hermeneutics, freely carry out their political campaigns with an appeal to religious texts and theological positions. Masiiwa Ragies Gunda, whose ideas on this topic have already been referenced above, further contends that political leadership of today borrowed the colonialist tools of utilising religion where it fits them so as to give religious legitimacy in "abuse of office". ${ }^{49}$

Bearing in mind that Christianity has the largest number of adherents in Zimbabwe and that the Bible is often quoted in public addresses, I assert that Zimbabwe is a "biblified state". ${ }^{50}$ Political public addresses in Zimbabwe are also referred to as rallies if the gathering is meant to address huge crowds. This is to make a distinction between a political meeting of a few people and that which is well publicised to attract huge audiences or supporters. It is at such gatherings that politicians sell their ideologies to the people. One of the biggest of these rallies was held in 1980 at Zimbabwe Grounds in the highdensity suburb of Highfield in Harare to mark the independence of Zimbabwe on 18 April 1980. The use of religious undertones is realised at both rallies and meetings that may not necessarily be for huge crowds. It was so in colonial Zimbabwe. As for instance, upon announcing the UDI, Ian Smith said "We have struck a blow for the preservation of justice, civilisation and Christianity, and in the spirit of this belief we have this day assumed our sovereign independence. God bless you all." ${ }^{51}$ According to Lapsley, a rebellion against the British crown to perpetuate white supremacy was carried out in the name of the Christian Gospel. ${ }^{52}$ In postcolonial Zimbabwe, Robert Mugabe's speech reflects the words

48 Joachim Kugler is a Roman Catholic Priest since 1988 and holds the Chair for New Testament Sciences at Bamberg University (Germany) since 2008. Before that he was Professor of Biblical Theology at Bayreuth University (1999-2008). He is one of the founding editors of "Bible in Africa Studies (BiAS)" series and has worked intensively with African postgraduate candidates in the last decade. His numerous works can be accessed online at: http://www.joachim-kuegler.de/4.html

The views of a number of BiAS scholars are collected in Gunda and Kugler, The Bible and Politics in Africa. See especially Tofa E. "The Bible and the Quest for Democracy and Democratization in Africa: The Zimbabwe Experience", in Gunda and Kugler, The Bible and Politics in Africa, 42.

49 Gunda, The Bible and Politics in Africa, 23, 26.

50 I do acknowledge usage of this term by Masiiwa Ragies Gunda when he discusses the need to be wary of an uncritical biblification of the public sphere. He contends that the Bible can be offensive, and to this I add that politicians and also other members of society have a tendency of extracting a single line of the biblical text that justifies their intentions and actions. Thus, when a person says "according to the bible", what it translates to is that the person has found a line that "legitimises" his or her action without engaging in the proper hermeneutical exercise.

51 Linden I. 1979. The Catholic Church and the Struggle for Zimbabwe. Salisbury: Longman, 87.

52 Lapsley, Neutrality or Co-option? 15. 
of the prophet Isaiah $2: 4^{53}$ when he said, "Surely this is the time to beat our swords into plowshares." ${ }^{54}$

On Independence Day, 18 April 1980, the Archbishop of the Roman Catholic Archdiocese of Harare blessed the new flag of Zimbabwe and the proceedings of the night of 18 April 1980. Prayer precedes almost every political gathering in Zimbabwe. Grace Mugabe seems to have taken a cue from this, as she had the audacity to say that "I think he (Mugabe) is the only gift from God that Zimbabwe has. He is the biggest gift we have." ${ }^{55}$ What remains a challenge is the level of sophistication that the audience have as recipients of religiopolitical messages coming from politicians. Some of the audience still hang on to the inherited mentality from the colonial era that what the leadership says is a reflection of the truth, and if they are to be regarded as good citizens the only option they have is to be gullible to the utterings of the politicians. Gunda contends that the Bible is used to benefit an inefficient and corrupt public institution..$^{56}$ There is an element here of an uncritical biblification of the public sphere, whereby the confessional use of the Bible is more of a smuggling of the divine in areas and events that are supposed to be judged in terms of efficiency and not religiosity. ${ }^{57}$

Just as Robert B Coote and Mary P Coote argue that the dominant idea behind the making of the Torah and several other Old Testament books is the legitimation of the ruling regime, ${ }^{58}$ is it not possible to assert that today politicians use the Bible to legitimate their hold onto power? The Cootes argue that despite the variety of their contents, the Hebrew Scriptures have one main subject, namely, rulers of Jerusalem between 1000 and 150 BCE and the people of Palestine under their rule. In similar fashion, the history of Zimbabwe is that of those who participated in the liberation struggle and those under their rule. The Hebrew Scriptures consist mainly of the scriptures of the temple cult of the god Yahweh in Jerusalem. The purpose of this cult was to legitimate rulers in Jerusalem, and this is what the scriptures are mostly about. Indeed, the writers of the scriptures became particularly active when rule changed hands and a new version of legitimacy had to be devised. ${ }^{59}$

There are parallels here not only to the religious rhetoric of Zimbabwe's ruling couple, but also to the news items that emanate from media under the control

53 Isaiah 2:4: "And He will judge between the nations, And He will render decisions for many peoples; And they will hammer their swords into plowshares and their spears into pruning hooks." New American Standard Bible.

54 Mugabe R. 2010. "What Mugabe Promised Thirty Years Ago" (Text of speech by Zimbabwe's Prime Minister designate), PoliticsWeb, 4 March.

55 2014. "Mugabe is a 'pastor' anointed by God, says Grace", New Zimbabwean, 7 October. Grace Mugabe made this claim while addressing about 300 pastors and their spouses who had visited her children's home in Mazowe.

56 Gunda, The Bible and Politics in Africa, 26.

57 Gunda, The Bible and Politics in Africa, 35.

58 Coote and Coote, "Power, Politics, and the Making of the Bible: The Torah".

59 Coote and Coote, "Power, Politics, and the Making of the Bible: The Torah", 344. 
of the state in Zimbabwe. This shows that in Zimbabwe there is a relationship between religion, state, and media. The state media selectively publish those religious events that are pro-government and in this case, it means proZANU-PF. As expressed earlier on in this chapter, the Constitution of Zimbabwe states that every citizen has a right to practice and propagate and give expression to their thought, opinion, religion or belief, whether in public or in private and whether alone or together with others. ${ }^{60}$ Borrowing ideas from Denise Meyerson's, ${ }^{61}$ analysis of religion and the South African Constitution, to what extent, if any, does the guarantee of freedom of religion contained in Section 60 of the Constitution of Zimbabwe prevent politicians from involving themselves in religious matters especially if this is done selectively and discriminatively? Further, is it "healthy" to extract and uncritically make use of those religious texts to promote a personal and political agenda?

Commenting soon after the First Lady's "meet-the-people campaign" of 2014, which saw her address political rallies in Zimbabwe's ten provinces, journalist Thomas Chiripasi concluded that Grace Mugabe's entrance into national politics has generated a lot of debate about President Robert Mugabe's succession plans at a time when his ruling ZANU-PF party is being torn apart by internal fissures. The First Lady believes that she has a calling from God to lead the country, although many Zimbabweans have mixed feelings over her surprise inclusion in the succession equation. ${ }^{62}$ Similar sentiments are expressed by journalists Peta Thornycroft and Damien McElroy, who argue that Robert Mugabe's much younger wife, a 49-year-old former typist, stepped into the battle to succeed the Zimbabwean president in an address to a ruling party rally in which she proclaimed she was the "chief advisor" to the nonagenarian leader. ${ }^{63}$ In her first full-length address to the ZANU-PF faithful, Mugabe vowed that her husband would seek re-election at the congress which is held once in five years due to be held in Harare in December 2014 and lashed out at unnamed cabinet colleagues of the Zimbabwean leader for what she called secret plots to force him from office. ${ }^{64}$ In her opinion, the ZANU-PF party would collapse without her husband in the top post.

The First Lady's "meet the people" campaigns were coloured by an incessant appeal to religion as she announced her entrance into the political realm. ${ }^{65}$ At

60 Constitution of Zimbabwe Section 60, 1(b). Cf. ACHPR, art 8; UDHR, art 18; ICCPR, art 18 .

61 Meyerson D. 2005. "Religion and the South African Constitution", in Radan P, Meyerson D and Croucher RF (eds). Law and Religion - God, the State and the Common Law. London and New York: Routledge Taylor and Francis Group, 107.

62 Chiripasi T. 2014. “Grace Mugabe's Political Ambitions Spark Debate on Mugabe Succession Plans", VOA Africa, 22 October.

63 Thornycroft P and McElroy D. 2014. "Grace Mugabe launches her political career at rally", Telegraph (U.K.), 4 October.

64 Chidza R and Manayiti O. 2016. "Mugabe to Rule from Grave - Grace", Newsday Zimbabwe, 26 May.

65 The "meet the people" campaigns were done in all the ten provinces of Zimbabwe soon after Grace Mugabe was elected as the Secretary of the Women's League 
a rally in Masvingo, her fourth one in the "meet the people" campaign, she announced that politicians such as Mrs Joice Mujuru, whose political demise she devised, was rejected by both God and the people because ange ave kunhuwa (she was stinking) before God. ${ }^{66}$ Joice Mujuru is a war veteran of the second Chimurenga. She served in the government of Zimbabwe from independence and by the time of her expulsion from ZANU-PF, and she had deputised Robert Mugabe in government for the past ten years. Reasons for her expulsion were spelt out by Simon Khaya Moyo, who was and still is the ZANU-PF secretary for information and publicity: "The grounds for Joice Mujuru's expulsion from ZANU-PF include but limited to the following; plotting to unconstitutionally remove the President and First Secretary of the party from office; orchestrating the 'bhora musango' (shoot the ball away from the goal target) campaign to the detriment of the party's interests ... engaging in behaviour unbecoming of a Vice President and second secretary of the party." 67 Grace Mugabe emphasised that people voted for her husband because he is God ordained to rule. She further claimed that even if her husband were to become physically incapacitated, she would have the strength to "push him to the office in a wheelbarrow as he is the only one chosen by God to rule Zimbabwe", 68 that "Mugabe will even rule from the grave" and that people should "vote for Mugabe's corpse in 2018". ${ }^{69}$

However, some Zimbabweans do not share her views. The most recent voice against the (mis)rule of Mugabe is that of the war veterans, who published a communique on the state of Zimbabwe's economy, the ZANU-PF party leadership and the way forward for the people of Zimbabwe. The fifth article of this communique states, "We note, with concern, shock and dismay, the systematic entrenchment of dictatorial tendencies, personified by the President and his cohorts, which have slowly devoured the values of the liberation struggle in utter disregard of the Constitution."70 The top leadership of the war veterans consists of Christopher Mutsvangwa (Chairman) and Victor Matemadanda (Secretary General). They have openly declared their support for Vice-president Emmerson Munangagwa to be Robert Mugabe's successor. An analysis of this shows that these people are defying the claims of Grace Mugabe that Robert Mugabe will "rule from the grave". It is also a real enjoyment of the constitutional right of freedom of conscience which allows people to freely express themselves. Be that as it may, concerted efforts were made to remove

of ZANU-PF.

66 Machiwenyika F and Maponga G. 2014. “'Faction leaders are appointees' First Lady warns supporters against being used, condemns abuse of power by bigwigs", The Herald, 10 October.

67 2015. "Zanu-PF expels Joice Mujuru; Slew of allegations cited; Plots traced as far back as 2004", The Herald, 3 April.

68 See Dawber A. 2015. "Zimbabwe's Robert Mugabe will rule until he is 100 from special wheelchair, his wife claims", Independent (U.K.), 22 November.

69 2017. "Grace says 'Zimbabweans will vote for Mugabe's corpse in 2018 or I take over ZANU-PF if Mugabe leaves'", YouTube, 17 February (posted).

70 2016. "Full Text: War veterans statement in dumping Mugabe", Nehandaradio.com, 21 July. 
the Mutsvangwa-led executive. This did not materialise. The only loss suffered by Mutsvangwa was that of being disappointed from war veterans cabinet post by Robert Mugabe.

There is also a widespread conviction that Robert Gabriel Mugabe did not win elections on a level political ground. Eliot Tofa asserts that it is important for any government anywhere to respect the sacrosanct right of citizens to elect a government of their choice and that for years, the people of Zimbabwe have been divested the right to elect people of their choice on the basis of an uneven political ground..$^{71}$ Violence has been used especially in 2000 parliamentary elections, the 2002 presidential elections and in the pre-electoral period of 2008 harmonised elections.

Besides Grace Mugabe's self-understanding as a "God-send", other members of the ZANU-PF party also appeal to religion to justify the existence of the party leadership. At a rally in Mazowe, Sarah Mahoka read and interpreted the Bible in a way of setting the stage where Grace Mugabe was the guest of honour. ${ }^{72}$ She read from the Shona Bible: "Munhu nemunhu ngaazviise pasi pevakuru" (Let every person be subject to the governing authorities, Romans 13:1, RSV). She said that people should respect the leadership of Robert Mugabe, since "people are going around saying VaMugabe vakura (the President is old) but the truth is that those who are saying so are not young either" ${ }^{\prime 3}$

At the same Mazowe rally, Vice-president Phelekezela Mphoko expressed reservations for those in the party intending to accede to power. He said that those who are power hungry will fall: "In the Bible, Satan had a beautiful voice but he was not satisfied. He wanted to be God. Because of that, he fell by the wayside." ${ }^{74}$ He says people should learn to be satisfied, and what this meant is that replacing and succeeding the current leadership should not occupy the thoughts of the party's followers.

Outside the leadership of ZANU-PF, some people are trying to influence the young to believe that Grace Mugabe is a godsend. Some have changed the traditional popular hymns into Grace Mugabe songs. An example is the National Association of School Heads which has approved a new version of "Amazing Grace! How Sweet the Sound". Tavonga A Chipadza has given it a new meaning by adding some lines of the "wonderful acts" done by the First

71 Tofa, "The Bible and the Quest for Democracy and Democratization in Africa". Eliot Tofa is a Zimbabwean academic. He is currently a lecturer of the Old Testament at the University of Swaziland.

72 Sarah Mahoka is an outspoken member of the ZANU-PF party and Hurungwe East member of the National House of Assembly. She has also been ZANU-PF Mashonaland West women's league chairperson. She is a strong supporter of Grace Mugabe. See http://www.pindula.co.zw/Sarah_Mahoka

73 Mlevu S. 2016. "Live from Chiweshe: Dr Amai Mugabe 'Meet the People Rally"', The Herald, 12 February.

74 2016. "Grace says not fooled by Mnangagwa's games, Kasukuwere throw weight behind her", New Zimbabwe, 2 December. 
Lady and his sign off reads, "The song is a Special Dedication to Her Excellence The First Lady Amai Dr. Grace Mugabe".

Judging from the huge crowds that gather at rallies addressed by the First Lady, it is easy to get the impression that she is enjoying a lot of support by members of the party. This is not the case! Instead, signs of polarisation within the party have never been more conspicuous. For instance, veterans of the second Chimurenga have shown their discomfort with the First Lady's political rise. The leadership of the Zimbabwe War Veterans Association has called for the banning of slogans and songs that praise anyone other than Robert Mugabe. This includes any proGrace Mugabe slogans and songs. With regards to succession, their preferred candidate is the 70-year old Emmerson Dambudzo Mnangagwa. ${ }^{75}$ Emmerson Mnangagwa is a Zimbabwean politician and personal aid to Robert Mugabe during the liberation struggle. He has been the vice-president of Zimbabwe since 2014 after the sacking of Joice Mujuru from the same post.

The use of religious rhetoric is not a prominent feature of Mnangagwa's political addresses. However, he has also inherited the art of the importance of bearing in mind that Zimbabwe has a religious landscape dominated by the Christian religion. On 26 September 2015, he addressed hundreds of Christians at the Harare Pan-African Leadership Initiative's National Presidential Prayer Breakfast. He quoted Bible verses and emphasised that those in leadership should shun corruption. ${ }^{76}$ Just as was the case in pre-Independence and postIndependence Zimbabwe, the post-Mugabe era is most likely to witness a continued manipulative use of religion. The danger of this is that religious texts are selectively used to maintain the status quo. Texts that are deemed subversive to the authority of those in power are avoided. Such usage of the biblical text is discouraged by what has come to be popularly known as Kairos Theology today.

\section{KAIROS THEOLOGY THEOLOGY AS A MODEL FOR CITIZENSHIP IN ZIMBABWE}

It is important to note that historically, Kairos Theology is traceable to the 1985 Kairos Document, which was drafted by leaders of the South Africa Council of Churches in apartheid South Africa. ${ }^{77}$ The political crisis of the then-apartheid

75 Emmerson Dambudzo Mnangagwa has been Robert Mugabe's right-hand man since the days of the struggle. As Grace Mugabe was celebrating her fiftieth birthday, Mnangagwa pointed out in his congratulatory and happy wishes speech that he has been with Robert Mugabe for more than fifty years. This was probably meant to remind Grace Mugabe that her marriage to Robert Mugabe could not take away the closeness that he has with Robert Mugabe, and this was also to send the message that Grace Mugabe remains a novice in the political game.

76 Nyakwenda L. 2015. “We must be righteous leaders: VP Mnangagwa”. The Sunday Mail, 27 September.

77 "Kairos" is a Greek word used in the Bible meaning a time to repent, a moment of truth. 
South Africa prompted the church leadership to introspect and spell out what the church was supposed to do amidst strife. The Kairos Document was a critique of theological models that were operative in South Africa at the time. It also made an attempt to propose an alternative biblical and theological model that would bring out the relevance of the Christian religion to society. Out of this, three models of theology came out. These are:

1. State Theology, which "is simply the theological justification of the status quo with its racism, capitalism and totalitarianism. It blesses injustice, canonises the will of the powerful and reduces the poor to passivity, obedience and apathy". ${ }^{78}$

2. Church Theology, which came from the speeches and statements of church leaders about the regime and the crisis of apartheid South Africa. These did not capture the faith of the majority of South Africans affected by the repressive laws of the government. Nevertheless, the speeches and statements of these church leaders were regarded by the media and generally society as the official opinions of the churches. Despite being critical of apartheid, the voices of these leaders relied more on stock ideas derived from Christian tradition and then uncritically and repeatedly applying them to the situation prevailing at the time. They spoke of reconciliation without truth, peace without addressing issues of justice and non-violence. ${ }^{79}$

3. Prophetic Theology, which was a call to have a spiritual, pastoral, and above all, prophetic response by Christians. In as much as it embraced the rich tradition of the Christian religion, it called for boldness and incisive responses to the present realities. It called for a response that did not give an impression of sitting on the fence but to clearly and unambiguously take a stand against all forms of oppression. ${ }^{80}$

Today, Kairos Theology is no longer restricted to the Kairos Theology of the South African context. It has spread its tentacles around the globe. As of 2010, Gary SD Leonard had managed to compile and edit thirteen theologies crafted out of the spirit of the original South African document. Among these is the 1998 Zimbabwean Kairos Document. This document specifies that it is a call to faith communities, civic organisations and all movements and individuals working for positive social, economic and political transformation of society for delivery from poverty, social inequality and to promote good governance. The "prophetic theology" model of the Kairos Document emphasises the need to remain true to tradition, true to the present needs, and shape a future characterised by justice - and not by enslavement to religious interpretations that perpetuate the status quo. For the Zimbabwean context, it becomes imperative that responsibility in the use of religious texts be guided by the consciousness to refrain from manipulatively appealing to religion and tradition when it comes to the choice of leadership.

78 Leonard GSD (ed). 2010. The Kairos Documents. Durban: Ujamaa Centre for Biblical and Theological Community Development and Research, University of KwaZulu-Natal, 9.

79 Leonard, The Kairos Documents, 15.

80 Leonard, The Kairos Documents, 23. 
A close analysis of the speeches by Grace Mugabe shows that the notion she advances is that it is not the ZANU-PF women that invited her to lead the women's league, thereby catapulting her into the powerful organ of ZANU-PF. Instead, she says it is the "voice of God" that has spoken. This is a way of inculcating into undiscerning minds the idea that what politicians say and do is from God. This is a dangerous position that creates political messianism and fundamentalism. It is therefore not proper for humans to use the name of God and that of religion to cover up for personal projects that may not be holy. Furthermore, the notion that some individuals are God-ordained to rule stifles the aspirations of those who did not take part in the liberation struggle, yet aspire to enter into the corridors of governance. At her political rallies, Grace Mugabe makes audacious claims of being rightly positioned to lead because she has been an apprentice of her husband in the political heritage of Zimbabwe.

\section{CONCLUSION}

Religion and the political heritage of Chimurenga are being used to render legitimacy to the rule of Robert Mugabe. Religion is being manipulated to justify the political rise of Zimbabwe's First Lady. However, this is coming at the backdrop of who really has the "right" machinery to advance his or her interests. For the Zimbabwean case, it is the President who has this. It is a question of those in power being in charge of the systems that allow them to remain in comfort zones. Since this cannot be shouted about, the only acceptable way to justify their hold on power is to appeal to a deity being the source of their authority. It is politics devoid of the ideals set out by the dictates of responsible citizenship. A model of citizenship for Zimbabwe calls for shunning the fallacy that those in power are elected by God. The general populace of citizens who are mainly religious are misled into imbibing a hasty generalisation of religious claims that those in power are God-ordained to do so. This shuts the door for opportunities of change, evolution, and an advancement of a citizenship critical of leadership. The culture of fear inherited from the colonial past has to be replaced by ideals of citizenship that restore social, religious, economic and political freedoms as enshrined in the Constitution of Zimbabwe. As noted above, there is a tradition of undue appeal to and (ab)use of religion by politicians as a way of maintaining the status quo. This renders it impossible to apply the tenets of citizenship, which call for democracy, social justice, efficiency and competency as a yardstick for the moral right to rule. The model of "Prophetic Theology" from the Kairos Document can be adopted for advancing a citizenship theory for Zimbabwe. 